\title{
Audit Within the Corporate Governance Paradigm: a Cornerstone Built on Shifting Sand?
}

\begin{abstract}
This paper is a case study-based investigation of aspects of the current paradigmatic approach to 'good' corporate governance with its focus on the interlinked roles of internal control and risk management procedures, internal audit and external audit, overseen and co-ordinated by a formal structure of board committees, in particular the audit committee. The evidence that we adduce from the study of four high-profile cases of perceived accounting and governance failure provides limited assurance that this approach will in fact be cost-effective or efficient in preventing further such cases of accounting and governance failure. Specifically, issues as to remuneration and fee dependence; lack of relevant knowledge and expertise; and social and psychological dependence upon executive management appear to have significantly and negatively affected the quality of decision-making of governance gatekeepers. This suggests that further consideration of relevant economic, institutional and cognitive/behavioural factors beyond the rational choice model of traditional economics should underpin future developments in required modes and structures of governance.
\end{abstract}

Key words: Corporate governance, audit, independence, competence, remuneration and fee dependence, heuristics, bias. 


\section{Introduction}

The paper sets out to identify and explore flaws in the corporate governance paradigm through a review of four cases, chosen as representative of the identified issues. From the late 1980s onwards there has developed a paradigmatic approach to 'good' corporate governance for companies in terms of an overall focus on appropriate internal control and risk management procedures within the relevant entity. Responsibilities for such procedures lie with the board supported by a formal structure of board committees and also by increased emphasis given to the role of internal and external audit. The development of this paradigm was given significant impetus by the influential COSO report, (COSO, 1992) in the US and in the UK the work of the Cadbury Committee (Collier, 1997), leading to the development of the present Corporate Governance Code (subsequently the 'Code', Financial Reporting Council, FRC, 2016). The Code is not statutory and adherence is not mandatory - but the London Stock Exchange listing rules require disclosure of non-adherence.

Against a background of a series of high-profile cases of perceived inappropriate accounting and corporate irregularities, the Sarbanes-Oxley Act (SOX) was passed in the US in 2002. The Act was a broad and wide-ranging attempt at further strengthening the regulatory underpinnings of the governance paradigm outlined above. With regard to auditing, the Act included requirements for: management to report on the effectiveness of internal controls and the external auditor to give an opinion as to the suitability of managerial assertions, the external auditor to report directly to the audit committee with respect to accounting policies critical to the overall picture presented by the financial 
statements, the prohibition of joint provision of certain non-audit services, and strengthening the position of the audit committee in terms of investigatory powers, resourcing, and the appointment and removal of the external auditor.

In the UK, post-Enron, the government set up a number of investigatory committees and commissioned reports re the role and duties of non-executive directors (Higgs, 2003) and the role and duties of audit committees (Smith, 2003), following earlier efforts aimed at updating the Code (e.g. Greenbury, 1995; Hampel, 1998; Turnbull, 1999). While a revised version of the Code (FRC, 2003) did not radically differ from the previous version, it required inter alia that, for larger listed companies, non-executive directors should comprise at least half the board, strengthened the role for the audit committee in monitoring the integrity of the company's financial reporting, and reinforced requirements for the external auditor to review the management of financial and other risks.

Although this paradigm commands widespread support, it has not gone entirely unchallenged. These challenges have come from those who consider that such a framework is both costly and likely to stifle enterprise and risk-taking, from those who question the ability of non-executive directors to satisfactorily perform the variety of roles expected from them, and from those who argue that the 'approved' governance mechanisms put in place have been demonstrably ineffective in checking corporate irregularity to date and are unlikely to be any more effective in the future (Clarke et al., 2003; Larcker et al., 2007; Bédard and Gendron, 2010; McNulty et al., 2013). 
This study primarily focuses on this latter line of argument and seeks to throw further light on factors which have acted to limit its effectiveness and to consider whether they are likely to continue to do so in the future. By exploring "how governance actors and institutions actually function" (McNulty et al., 2013, p. 183), the analysis also contributes to the literature which studies and reports activities in practice with view to more closely capturing the dynamic, interactive nature of corporate governance (Gendron and Spira, 2009; Whittington, 2011; Brennan and Kirwan, 2015) and limits to monitoring (Cullen and Brennan, 2017).

One could contemplate the possibility of the commercial world rejecting the existing governance paradigm, to replace it with an alternative. With an emphasis on organizations' value-creation over time, the International Integrated Reporting Framework ('IIRF' - IIRC, 2013) might be a potential candidate to allow reflection on the issues raised in the present paper - namely remuneration and fee dependence, lack of expert knowledge and expertise, excessive dependence on executives, and impacts on the quality of decision-making from social/psychological factors. While empirical testing of this conjecture is beyond the present paper, we raise the potential of alternative frameworks to emphasise the depth of the issues at hand and will further reflect on this in the conclusion. ${ }^{i}$ 


\section{Issues as to Methodology and Data}

This paper does not seek to adopt or articulate any particular epistemological or theoretical perspective to explain or underpin its findings. In terms of methodology it might perhaps be categorised as interpretative, archival-based case study research. The advantages and disadvantages of such a research approach have been extensively rehearsed and it is not the purpose of this paper to review them in any detail. The cases under review highlight critical flaws in the existing corporate governance paradigm that we aim to examine. The selected cases are deemed representative of subsequent scandals, including those related to the global financial crisis ('GFC') of 2007/08 (House of Lords, HoL, 2011; US Senate, 2011) and subsequent scandals (US Senate, 2013).

Much academic work is based on large-scale empirical investigations, which have an important role to play, but we suggest that all too often such investigations are unable to discuss the minutiae and lack the insight afforded by case studies. Empirical research into factors affecting corporate governance reveals ambiguous results (Larcker et. al., 2007) and there are numerous calls for research into actual governance practices (McNulty et al., 2013), the more dynamic and interactive nature of governance (Brennan and Kirwan, 2015), and for exploratory, descriptive or transformative studies with a focus on psychological and sociological perspectives (Bédard and Gendron, 2009). In a similar vein, Brennan and Kirwan (2015) posit that much prior research fails to adequately capture realworld complexities of governance, while Bédard and Gendron (2010, Abstract) suggest that: “... very few studies are exploratory, descriptive or transformative. Psychological and sociological perspectives of analysis are neglected...", 
supporting calls for research approaches that explore corporate governance processes in action (Ahrens and Khalifa, 2013; McNulty et al., 2013).

The paper comprises a review of four cases of perceived accounting and governance failure, namely WorldCom, Tyco, Xerox and Hollinger. Through this review, the paper seeks to add to knowledge as to the strengths and limitations of the paradigm of 'good' corporate governance currently advocated in North America, Europe and, through the offices of the OECD, IFAC and others, worldwide. The cases relate to companies registered with the Securities and Exchange Commission (SEC) although all the companies are, or were, multinational. While the selected cases occurred just after Enron, and might thus appear somewhat dated, they serve to demonstrate the flaws in the existing governance paradigm.

Given the limited number of cases, seeking to derive inferences therefrom may be open to criticism on a number of grounds - in particular in respect to a lack of representativeness. There are approximately 10,000 publicly listed companies subject to SEC regulations in the United States and Francis (2004) suggests that the fact that SEC Accounting and Auditing Enforcement Releases (AAER) through the ten year period (1994 - 2003) averaged only 149 per year is indicative of a relatively low overall rate of corporate governance failure. ${ }^{\text {ii }}$ However, Coffee (2005), drawing on reports from the US General Accountability Office (GAO), suggests a much more widespread malaise with a rapidly increasing trend in earnings restatements which rose eight-fold between 1995 and 2004 to reach 414 
in that year, with revenue recognition issues being the single factor responsible for most such restatements.

There have been many scandals since the events outlined in this paper, which call into question the quality of corporate governance, auditing, internal controls, risk management, and the contribution of audit committees, but we deem the selected cases representative of the issues under discussion and representative of other scandals, the fact that all four cases are US-based is coincidental. And while we note that WorldCom has been investigated previously, the other cases have attracted less comment. Within the cases looked at there is significant variety in terms of the nature of the entity under examination. These differences relate in part to size although all are, or were, very large corporations, to the nature of their business, and to their pattern of ownership structure and management style. There are also differences in the nature of the irregularities which took place. In two cases the primary impropriety related to accounting manipulation, whereas in the other two cases the main concerns related to inappropriate abstraction of corporate assets on a heroic scale by senior management - rather than on accounting issues per se. Further questions arise as to the extent to which the companies under examination had fully embraced and implemented the internal control and governance paradigm outlined above - although all complied with the minimum SEC requirements.

In terms of collection of the underlying information the main sources are ex post investigation, whether in terms of reports of bankruptcy examiners (WorldCom) or SEC action against the company, its officers, and on occasion its auditors. In 
one of the four cases (Hollinger) there are also the reports of inquiries internal to the company, and the information available in all cases is voluminous. An enormous wealth of detail is provided in these reports, but the inquiries do not all have a common purpose: those of the bankruptcy examiners being focused more on claims over remaining assets, whereas those of the SEC relate more to a desire to prevent corporate irregularity and to ensure the provision of appropriate financial information to the capital markets. Although all of the inquiries identify failings in individual aspects of corporate governance, none of them had the purpose to investigate the wider issue of whether the overall corporate governance framework is appropriate.

We suggest that the existing paradigm remains flawed in that the subsequently implemented regulatory changes predominantly rely on well-tried means such as more rules and regulations, greater monitoring, closing of technical loopholes, and increased reliance on directors and external auditors in implementing these changes. This appears to leave the paradigm exposed to recurring failures from the issues outlined in this paper, issues which likely contributed to subsequent corporate scandals. The next section of the paper sets out the nature of the issues of interest in the four cases chosen and seeks to identify those aspects of the nature and practice of corporate governance which are relevant to this paper.

\section{The Cases}

\section{WorldCom}

On June 9 2003, the US Bankruptcy Court of New York issued an interim report (Thornburgh, 2003) which expanded on the court's earlier findings (Thornburgh, 
2002) of lack of corporate governance, mismanagement, and concern regarding the integrity of WorldCom's accounting and financial reporting functions. Amongst the numerous incidents of mismanagement, corporate governance failure, and accounting irregularities, the most salient related to the overstatement of reported profitability by inappropriately capitalizing very significant elements of operating costs. In June and August 2002 WorldCom restated its previously filed financial figures by $\$ 3.8$ and $\$ 3.3$ billion respectively primarily in relation to this failure to charge operating costs to the profit and loss account appropriately. The trigger for these restatements in part was an internal audit investigation into the capitalization of operating costs - although this only took place after the departure of WorldCom's dominant CEO and the replacement of Andersen as the external auditor by KPMG. Indeed, an internal audit of capital expenditure a year previously had become aware of the existence of $\$ 2.3$ billion of 'corporate accruals' in relation to capital expenditure but had made no attempt to verify the nature and propriety of these 'accruals'.

Internal audit at WorldCom was an in-house department first set up in a small way in 1993 but which had subsequently grown in numbers - although it was never heavily resourced relative to internal audit departments in other companies of a similar size. Formally it had a dual reporting responsibility - reporting to both the Chief Financial Officer (CFO) and to the audit committee, although the bankruptcy examiner had no doubt that its functional reporting responsibilities were to the CFO and that its existence and role were very much at the behest of senior management. ${ }^{\text {iii }}$ This perceived dependence upon executive management for resources led to the work program concentrating almost exclusively on 
operational aspects, focusing on audits and projects that would be seen as adding 'value' to the company, and seeking to identify ways to maximise revenues, reduce costs and improve efficiencies. It did not involve itself in financial auditing per se, and even when it did check accounting entries to subsidiary ledgers it did not normally follow these through to the general ledger - apparently to avoid the perception of the duplication of work with the external auditors Andersen.

The report of the bankruptcy examiner also provides evidence of lack of uniform procedures within the internal audit department relating to the conduct of audits, preparation of reports, review of management responses and follow up procedures; a lack of co-operation with internal audit by line management; limited access by internal auditing staff to the company's computerised accounting and reporting systems; unwarranted influence by management in the preparation and negotiation of the internal audit reports; and a lack of a systematic approach in relation to highlighting serious internal control weaknesses and tracking of management responses and corrective action taken.

Another aspect of the corporate governance paradigm highlighted by the WorldCom case relates to the co-operation and liaison, or rather lack of it, between the internal auditors, the external auditors and the audit committee. WorldCom had an audit committee constituted in accordance with the requirements of the Blue Ribbon Committee (1999) and, over the relevant period, consisting of four non-executive directors with varying degrees of business experience and expertise. The committee met three to five times a year and at 
each meeting would, inter alia, receive an information pack prepared by the Director of Internal Audit and on occasion would receive presentations from her. Formally, internal audit reported to the audit committee but as the report notes: 'while most members of the Audit Committee perceived the Internal Audit Department as reporting to the Audit Committee, that was not the case, functionally or practically. iv The audit committee only received executive summaries of the actual audit reports, rarely the full reports. Perhaps more importantly, the members of the audit committee appear to have assumed there to be a much greater degree of co-ordination between internal audit and external audit than actually took place, and were not aware that Andersen did not receive copies of the internal audit reports.

In fact, communication between internal audit and external audit was very limited, being largely restricted to joint attendance at the meetings of the audit committee. The lack of communication between the two is highlighted in relation to the ability of the external auditor to provide annual reassurance to the audit committee on the absence of material weaknesses in the company's systems of internal control, notwithstanding the existence of internal audit reports some of which documented significant such weaknesses. It also appears to have been a factor in the failure referred to above of internal audit to conduct meaningful financial audit, even when aware of circumstances which might have been expected to prompt further investigation.

\section{Tyco}

Tyco was a manufacturing and service conglomerate involved in fire and security 
services, electronics, healthcare products, and undersea telecommunications networks. Here the issues of concern lay with the ability of senior management to obtain large and undisclosed loans from the company. The summary of the SEC complaint against its senior executives commences:

"This is a looting case. It involves egregious, self-serving and clandestine misconduct by the three most senior executives at Tyco International Ltd. ("Tyco").

Apart from this, and as detailed in the separate SEC enforcement release ${ }^{\mathrm{vi}}$ in respect to the actions of Richard Scalzo, the PwC partner in charge of the audit, there were accounting issues associated with year end adjustments and the treatment of bonuses and stock options, but the main issue was level of unauthorised and undisclosed borrowing by executives. A significant aspect of the SEC's case against Scalzo and PwC was the failure of the external auditors to identify, at an early stage, the fact that the loans supposedly to assist the payment of tax on stock options were in fact being utilised for a variety of other purposes, despite the fact that at an early stage the auditors were provided with evidence strongly suggestive of this. Notwithstanding an awareness of the extensive nature of the loans to management, and a whole range of issues relating to accounting treatment and disclosure which raised serious questions as to the integrity of senior management, $\mathrm{PwC}$ continued to conduct their audit as if these concerns were not present. As the relevant enforcement release notes:

"In contrast to the requirements of GAAS, Scalzo conducted the financial statement audits for Tyco's fiscal years 1998, 1999, 2000, and 2001, under 
an assessment of risk that remained unchanged by facts and events that called into question the character and integrity of Tyco's most senior management."

The case also illustrates external audit failings in bringing audit findings to the attention of the audit committee. The enforcement release separately refers to Scalzo's failure to inform the audit committee of his knowledge that loans designated to pay the tax on vesting stock had been used to exercise tens of millions of dollars of stock options; his knowledge of the existence of tens of millions of dollars of non-interest bearing loans made to senior executives or that Tyco's management had repeatedly rejected PwC's recommendation that these loans should be disclosed; his knowledge of the existence of 'last minute postperiod adjustments' designed to offset expenses improperly against general reserves; and his knowledge that Tyco had provided false information about a finder's fee to the Chairman of the Board.

\section{Xerox}

Xerox's accounting practices in the years immediately preceding, and including, the year 2000 were the subject of extensive investigation by the SEC, as reflected in the following extract from the SEC complaint against its auditors KPMG.: ${ }^{\text {vii }}$

"From at least 1997 through publication of the company's 2000

financial report, Xerox abandoned its obligation to accurately report its financial condition ... by using undisclosed manipulative accounting devices ... These devices defeated the bedrock purpose of 
the accounting rules and public disclosure — to fairly, accurately and timely inform the public of the actual financial performance of the company."

Xerox employed a range of accounting devices to enable it to manipulate its earnings numbers. Some were relatively straightforward (for example the creation of unnecessary reserves); others, relating to the valuation of the equipment leased by Xerox, were a little more complicated, but all had the purpose of increasing the amount of earnings which could be reported. In respect to corporate governance it was the auditors KPMG that drew the brunt of the SEC's wrath in its litigation complaint. The SEC characterised the actions of the defendant KPMG partners in the following terms:

"Although the defendants occasionally voiced concern to Xerox management about the "topside accounting devices" ... the defendants did little or nothing when Xerox ignored their concerns and continued manipulating its financial results. The defendants then knowingly or recklessly set aside their reservations, failed in their professional duties as auditors, and gave a clean bill of health to Xerox's financial statements."

Neither the Xerox audit committee nor the internal audit function appear as other than bit players in the separate SEC complaints against the Xerox senior management and the auditors, although there is passing reference to the extent to which KPMG communicated its concerns to the audit committee as the following 
extracts from the SEC's complaint illustrate:

"Finally, Safran told Conway and Boyle [other involved KPMG partners] that KPMG had a "professional obligation" under GAAS to communicate his concerns to the Xerox Audit Committee. However, Conway, Safran and Boyle did not raise any such issues at the next Audit Committee meeting, and Safran ultimately signed off on the 1999 financial statements with Conway's and Boyle's knowledge and concurrence."

In a report to the audit committee, also in early 2000, Safran stated:

"...we believe the Company needs to improve its analytic processes and controls to confirm that the assumptions used are reasonable and that appropriate fair values are derived from existing methodologies."

But he did not follow this through further and in October 2000,

"[H]e sent the Xerox Audit Committee an analysis of Xerox's revenue allocation methods which did not mention the skepticism of KPMG auditors in Europe and accepted without question management representations that the margin normalization device was appropriate. "viii

In this respect the SEC concluded: 
"The KPMG defendants did not comply with their professional obligation under GAAS or the securities laws to require Xerox to change its financial reporting, or, if Xerox declined to do so, to qualify KPMG audit reports, issue no report at all, resign from the audit and, if necessary, notify the Commission..."

\section{Hollinger}

Conrad Black built up, from the 1960s onwards, a newspaper and publishing empire initially in Canada, but latterly expanding to include significant titles in the US, the UK, and Israel. As the business interests expanded, a corporate structure evolved marked both by high levels of debt and a pyramid arrangement together with shares with different voting rights whereby Black, supported by key associates and by virtue of a majority stake in Ravelston (the company at the head of the pyramid), was able to retain all but complete control of the business entities (the appendix illustrates the group structure). Following significant losses in 2002 and 2003 and allegations of impropriety a special internal committee, advised by a former SEC chairman, was set up by Hollinger in June 2003 to investigate the allegations of impropriety and breach of fiduciary duty. The Breeden Report filed with the SEC and published in August 2004 is uncompromising in its support of these allegations, stating on its opening page:

"[T]his story is about how Hollinger was systematically manipulated and used by its controlling shareholders for their sole benefit, and in a manner that violated every concept of fiduciary duty. The aggregate cash taken by 
Hollinger's former CEO Conrad M. Black ... and associates represented 95.2\% of Hollinger's entire adjusted net income during 1997-2003."

The Report documents a tale of what it terms 'corporate kleptocracy' including the use of company assets for personal perquisites for Black and his wife, an incentivisation scheme on a portfolio of hi-tech investments which paid Black and associates $\$ 5.3 \mathrm{~m}$ notwithstanding overall portfolio losses of $\$ 67.8 \mathrm{~m}$, excessive management fees, sales of assets to Black and associates below market value, and much else besides.

The governance structure of Hollinger over the relevant time period comprised a Board of Directors (executive and non-executive), an executive committee, an audit committee, a compensation committee and a stock option committee. There was no separate nomination committee. Throughout the period from early 1998 through to 2002 the composition of all of these committees was unchanged. The audit committee comprised three non-executive directors, Richard Burt, a director since 1994, former US ambassador to Germany, chief negotiator in strategic arms reduction talks from 1989 to 1991 and subsequently a partner in McKinsey; Josee Kravis, a director since 1996 and a senior fellow of the Hudson Institute since 1994; and the Chairman, James Thompson, a director since 1994, governor of the state of Illinois from 1977 to 1991.

The compensation committee had just two members (Burt and Thompson) as did the stock option committee. Thompson chaired both of these committees, both of which had established charters detailing their composition and responsibilities, 
with the specific responsibilities of the audit committee being set out annually in the $14 \mathrm{~A}$ proxy filing to the SEC. This filing made clear the responsibility of the audit committee for reviewing both the level of management fees charged by the holding company and other related party transactions. ${ }^{\mathrm{ix}}$ However, in the outcome the exercise of this responsibility left much to be desired and, although acknowledging that on many occasions the audit committee received inappropriate and misleading information from the executive directors, the Report is relentlessly critical of the performance of the audit committee. For example in respect to the management fees charged:

"The Audit Committee never asked for (or seemed to think it worth knowing) any information about Ravelston's overall costs, revenues or profits. ... More fundamentally, the Audit Committee didn't appear to understand exactly what services Ravelston actually provided for Hollinger, or what the cost or value of those services might be."

and the approval of the various non-compete arrangements, in particular those relating to the sale of Hollinger's Southam newspaper chain to CanWest in 2000:

“ ... the Audit Committee approved $\$ 51.8$ million in payments to Black and his Ravelston associates ... They did not seek any advice from any financial or legal experts independent of Black and Ravelston about the appropriateness or amounts of the payments ...[or] ask the obvious question of why Black, Radler and the other individuals were entitled to receive payments for doing something they were already obligated to do by virtue of their status as Hollinger officers." ${ }^{\mathrm{x} i}$ 
and in circumstances where the audit committee was in possession of full information but failed to act in a meaningful way. For example in respect to the incentivisation plan:

\footnotetext{
“...they approved the Digital Incentive Plan without obtaining independent

legal or financial advice concerning the structure of the plan or whether its terms were, as Radler had represented, consistent with industry practice. "’xii
}

In attempting to determine why the audit committee failed so spectacularly, aspects of interest include those relating to the expertise of the audit committee, the nature of their appointment, potential remuneration and fee dependence, and personal and social relationships with executive management. Two of the committee members, Burt and Thompson, had extensive political experience and Kravis had been a high-profile economist/journalist. Thompson was a trained lawyer and Kravis had worked as a financial analyst in the early years of her career - but it is open to question whether they satisfied the audit committee charter requirements that each of the members of the committee should be financially literate and that 'at least one member of the audit committee shall have accounting or related financial management expertise'. However, where in some cases the complexity of certain of the transactions and the nature of the financial instruments employed obfuscated the more basic lack of integrity of senior management, it is difficult to say that this was the case at Hollinger.

Of course the audit committee members were dependent upon executive management for their information as to the transactions that they were required to approve, and this lack of an independent knowledge-base may have greatly 
restricted the effectiveness of the committee. This reliance upon executive management for information and a reluctance to seek alternative sources of information is referred to throughout the Report:

“... the Special Committee discovered a pattern of misleading statements to the Board and the Audit Committee surrounding related-party transactions. In addition to making false statements, we also found many cases in which Black ...or others failed to tell the Board or the Audit Committee key facts necessary to fully understand transactions or payments ..."

However it continues:

\footnotetext{
"These reasons do not seem enough, however, to justify the Audit Committee's passivity and its acquiescence to everything Black proposed."
}

And in this context it is necessary to consider the independence of the nonexecutive directors and their financial and other links with Black and his associates. In 2000 each director was entitled to an annual director's fee of $\$ 32,500$ and a fee of $\$ 3,000$ for each board or committee meeting attended. In addition there was a not negligible annual stock option entitlement for nonexecutive directors (a practice strongly discouraged in the UK for LSE listed companies, although not formally prohibited) which appears to have been taken up fully or nearly so by all those entitled.

\section{Reflections and Insights}

Insights gathered from the review of the above cases suggest that neither 
individually nor collectively can the component parts of the present paradigm of 'good' corporate governance be taken to provide that level of reassurance and protection for investors and other corporate stakeholders which the regulators on both sides of the Atlantic believe them to be capable of. ${ }^{\text {xii }}$ In this respect the evidence presented above may be interpreted as reinforcing the view that there are commonalities in the forces that shape the activities and function of these separate governance activities which are likely to weaken their ability to fulfil the role ascribed to them by regulators and others. These are to an extent overlapping and interrelated but for discussion purposes may be categorised in terms of: remuneration and fee dependence, lack of relevant knowledge and expertise; and excessive dependence upon executive management (including unwarranted deference to dominant personalities, insufficient scepticism, effects of bias and heuristics). To take each in turn:

\section{Remuneration and Fee Dependence}

Non-executive directors, external and internal auditors are remunerated by the company. If they consider that this stream of remuneration is likely to cease consequent upon their behaviour then that behaviour may, and indeed is likely to be, modified accordingly. Remuneration and fee dependence issues relating to external auditors have been extensively aired over many years with particular concerns being raised both as to dependence at individual and office level and as to the enhanced dependence caused by the associated provision of non-audit services to audit clients. Notwithstanding the regulatory attempts to mitigate such dependencies, for example in terms of strengthening the powers of audit committees with respect to determining auditor remuneration and in prohibition of 
audit partner remuneration being linked to the sale of non-audit services, arguably remuneration and fee dependence contributed to external audit failure in a number of the above cases, perhaps most notably at Xerox where the SEC noted that:

“KPMG had been Xerox's auditor for 40 years and had generated over $\$ 56$ million in non-audit fees during 1997-2000, as well as $\$ 26$ million in audit fees. No KPMG defendant wanted to risk antagonizing the client or resigning the engagement." xiv

The levels of the remuneration of non-executive directors varied in the cases under consideration. However even at the more modest levels of remuneration the amounts were far from negligible either in terms of an individual income or in relation to the number of hours worked.

\section{Knowledge and Expertise Dependence}

Audit committees, external auditors and internal auditors each have to possess competence, knowledge and the power to investigate matters of concern if they are to fulfil their duties appropriately. Wolnizer (1987) and Power (1997) have both identified the critical need for auditors to have a knowledge base which enables them to form an independent opinion as to the quality of financial reporting. In the absence of such knowledge, an audit is likely to degenerate into no more than an acceptance of management representation and be of correspondingly little value. 
In the cases outlined above the extent of the knowledge of the parties differed in each case. Arguably in none of the cases did any of the parties have the full knowledge of the facts as revealed by subsequent events and ex post investigation, but there is little doubt that in respect to Xerox the external auditors were aware of the nature of the questionable accounting practices being followed but accepted them as appropriate. In Tyco the auditor was clearly aware of factors indicative of impropriety but appears to have limited the extent and depth of further investigation which would have revealed the full scale of these improprieties. In Hollinger, KPMG appears to have played a role which was neither central nor peripheral. They were auditors for all the main companies in the pyramid and cannot have been unaware of the level of management fees charged or the relationship, if any, between these fees and costs incurred - but they appear to have raised little if any concern and neither KPMG nor Torys (Hollinger's legal advisers) alerted the audit committee to any concerns as to either the level of management fees or the propriety of the non-compete payments.

In WorldCom it is not clear whether Andersen was aware of the significant level of 'corporate accruals' - although perhaps they should have been. Although external auditors have both the capability, and the statutory power to investigate matters to the full, subject to control over work programme and resources, this is not so with respect to audit committees and non-executive directors more generally. A number of the cases (Hollinger and Xerox) document a lack of understanding by audit committee members of the issues at stake, a lack of understanding exacerbated by an inadequately sceptical approach, control of information flows (including internal audit reports) to the audit committee by 
executive management, and a striking reluctance by external auditors to articulate their concerns to audit committees.

The board's expertise may not always extend to that of the accountants involved in external audits, but they too have a duty to be sceptical and to ask questions if they do not understand a transaction. In the surveyed cases, they apparently did not do this. Still, insufficient knowledge and expertise may not always be at the heart of the issue. In the case of Hollinger, no deep accounting knowledge, per se, was required, just a degree of common sense and a sense of scepticism before signing away shareholders' money.

\section{Social and Psychological Dependence}

Thus far, we have focussed mainly on economic factors affecting fraudulent behaviour, poor monitoring and audit. It is, however, increasingly being recognised that, in addition to economic factors, social/psychological and emotional factors may have a large part to play in inducing egregious managerial behaviour and acquiescence by gatekeepers (Coffee, 2001, 2003). ${ }^{\mathrm{xv}}$ In this section, we briefly consider this research and relate it to our case studies.

If managerial fraud and gatekeeper acquiescence are entirely due to agency and incentive problems, this could be relatively easily addressed through improving the incentive scheme and through tougher regulation and legal sanctions. Indeed, Becker (1974) provided the seminal work on the economics of crime where perpetrators rationally weigh up the benefits of crime against the costs of crime 
accruing to them. Hence, according to Becker, perpetrators are fully-rational, allcalculating, unemotional, self-interested maximisers of expected utility.

Examination of our cases suggests some very self-interested rational calculative behaviour, in the vein of Rockness and Rockness (2005), Akerlof and Romer (1993), and Becker (1974). The SEC reported that Tyco was a looting case involving self-serving and clandestine misconduct by senior executives, which implies that re-design of the incentive schemes, tougher punishments, and stronger regulation, might be sufficient to prevent future scandals and fraud, a line of thought that can be extended to apply to gatekeeper behaviour.

However, behavioural economists and psychologists note that, in addition to economic factors and intentional fraud, social/psychological and emotional factors may play a large part in inducing egregious behaviour (Sunstein et al., 1998; Rabin, 2002). In Schrand and Zechman's (2012) 'slippery slope to fraud' analysis, for example, overconfident executives with an optimism bias initially and unintentionally overstate earnings and then become entrapped in intentional mis-statement to cover it up. Furthermore, scholars have noted the role played by group-think (Leslie, 2010), exacerbated by the existence of dominant personalities (FRC, 2011), in fraud-commission. Another important social/psychological factor affecting fraud behaviour is the development of psychological 'closeness' and empathy (the 'familiarity threat' - APB, 2009; Long, 2009) between corporate management and external auditors, which may lead to auditors 'turning a blind eye' (consciously or unconsciously) to egregious behaviour (this has resulted in a debate on mandatory auditor turnover). This suggests that economic 
considerations of fraudulent or negligent behaviour, with the suggestion of tougher regulation and punishment as a solution, are only part of the story. Instead, policy-makers may also need to consider the psychological, behavioural and other subconscious factors that may have contributed to allowing managerial misdemeanours to take place.

In all of our cases there is evidence of these social/psychological factors at play. In the WorldCom case, we noted numerous incidents of mismanagement (suggesting a possible accumulation of fraud, with the management on a 'slippery slope'). We also saw that earnings were only restated after the departure of the existing dominant CEO (the 'group-think' effect), and replacing existing auditors Andersen with KPMG (the empathy, blind-eye turning effect). Finally, we noted the dependence between internal audit, the CFO, and the audit committee. In the Tyco case, it appears that Richard Scalzo, the PwC audit partner in charge of the audit, knew of the looting behaviour of the executives in terms of the misuse of loans, but ignored this. The Xerox case demonstrates the slippery slope to fraud, with increasing misreporting over several years, together with blind-eye turning by the auditors, PwC: we noted that PwC 'occasionally voiced concern to Xerox management about the 'topside accounting devices', but then proceeded to ignore these concerns, and 'gave a clean bill of health.' Hollinger provides an example of a complex governance structure, with close and potentially-empathetic relationships across the organisation and governance committees. For example, we noted that Hollinger's audit committee may have failed in its duties due in part to its members' personal and social relationships with executive management. 
Thus, details emerging from our cases indicate that auditors may have known, and certainly were in a position to know, that particular accounting treatments were highly questionable. These gatekeepers would appear to have lowered their guard - or perhaps even looked the other way - when warning signs were clearly visible (Prentice, 2000a). Although this view is not uniformly shared, Morrison (2004), for example, argues that Arthur Andersen was made a scapegoat by US authorities for its involvement with Enron, the string of poor quality audits in which the firm had previously been involved does not support a positive interpretation of the quality of internal control within the firm (Turner, 2005).

Furthermore, in recent years all of the big auditing firms have been associated with issues of audit quality at major clients which might be seen as an indication of generic problems which cannot be attributed just to the failings of individual partners or firms. While, as noted by Clarke et al. (2003), the flexibility provided by accounting standards and the nature of accruals accounting indubitably makes the task of auditors and other parties with governance responsibilities a difficult one, we suggest that the failings identified in the cases under consideration go far beyond those which can be wholly attributed to the imprecise nature of financial reporting in an uncertain world.

Concerns about the degree of, and consistency in, the application of independence and competence during audits of listed companies are reflected, inter alia, in annual reports on audit quality inspections of the Big Four and other significant firms by the FRC's Audit Inspection Unit (AIU) and its successor, the Audit Quality Review (AQR). Highlighted in the inspections from 2009 to 2017 is a 
substantial continued need for firms to improve consistency of application of professional scepticism, auditor independence and audit quality (AIU 2009, 2010, 2011, 2012; AQR 2013, 2014, 2017). Similar concerns are expressed by inspections by the PCAOB $(2008,2011 b, 2015)$, and the Auditing Practices Board (APB, 2011, 2012).

Whether audit deficiencies and audit failures are seen as having been caused by an insufficient application of professional scepticism (PCAOB, 2008, 2011a,b, 2012, 2015; Centre for Audit Quality 2010; Messier, et al., 2012; Glower and Prawitt, 2014), or were due to insufficiencies in the application of professional skill or competence (IES 8, IAESB, 2008), behavioural and situational factors have a critical impact on the consistent and adequate application of either of these ingredients to audit quality. Here we would argue that the standard corporate governance template - based on the rational choice model of traditional economics - fails to take sufficient account of the psychological and social pressures on monitors and gatekeepers, and their effect on the quality of decisionmaking (Gilovich et al., 2002).

Factors known to systemically distort judgment include conflicts of interest, deference to authority, peer pressure, emotional attachments, and inappropriate reliance on previous experience and decisions (Hoggarth, 1991; Langevoort, 2001a; Bazerman and Malhotra, 2006; FRC, 2011). The auditing process is particularly susceptible to cognitive bias given the typical operation of audit under conditions of uncertainty, proximity to client, group effects, and prior beliefs (Bédard and Wright, 1994; Bazerman and Watkins, 2004; Prentice, 2000b, 2012; 
Moore et al., 2010). Auditors have been found susceptible to the representativeness heuristic (Smith and Kida, 1991; Kellogg and Kellogg, 1991), anchoring and adjustment (Joyce and Biddle, 1981a,b; Hirst and Koonce, 1996), availability (Bonner and Pennington, 1991; Haynes and Kachelmeier, 1998), cognitive dissonance and escalation of commitment (Weick, 1983), preference for confirmatory rather than disconfirmatory evidence (Waller and Felix, 1984), selfrationalization (Peecher, 1996), group-think (Janis, 1972; Scharff, 2005), where the group takes over individual behavior to impede rational decision-making, and finally unwarranted deference towards dominant personalities (Padilla et al., 2007; Forbes and Watson, 2010).

Prior studies would appear to primarily focus on implications for governance from issues related to remuneration and fees, as well as knowledge and expertise, at the expense of a discussion of the quality of decision-making processes. While the present paper deems issues related to independence and competence of significant and continued importance, it additionally suggests a need for a consideration of the impact of social/psychological factors on judgement and decision-making processes in governance. The need for such a discussion has not gone entirely unnoticed, and the FRC (2011) and the APB (2012) have given prominence to the heuristics and biases approach to human judgement. Recognizing that technical approaches to better audits are useful to an extent, but largely fail to address behavioural issues impacting on judgement during audit and board deliberations, the FRC and APB suggest a focus on the quality of the decision-making process itself, with an emphasis on the implementation of proactive bias mitigation procedures. The failure to systematically employ measures 
aimed at bias mitigation during the audit process suggests that audit will remain a cornerstone built on shifting sand.

\section{Conclusion}

The evidence presented in this paper provides at best muted support for the viewpoint that seeking to reinforce the existing corporate governance structure along the lines advocated in both North America and the UK will necessarily act to prevent any such future failures of corporate governance. The repetition of corporate scandals and the recurrence of more Codes and regulations since the described events not only put in doubt the effectiveness of applied approaches, but raise concerns whether the repeated Codes are a legitimation device by regulators mainly aimed at restoring the public's faith rather than actually serving to improve governance. ${ }^{\mathrm{xi}}$ Improvements in corporate governance put in place subsequent to the described events, may have stemmed but have not prevented corporate abuse from occurring and an extended layer of regulation, unless there is further consideration of the appropriate institutional structure within which 'good' corporate governance takes place, may turn out to be costly but largely

ineffective. $^{\text {xvii }}$ The increase in costs is already with us in terms of increased expenditure on internal and external audit. ${ }^{\text {xviii }}$

Whereas issues of remuneration and fee dependence have been extensively discussed in the prior literature, wider, largely non-economic, relationships in terms of social/psychological and emotional factors have been accorded less prominence, although arguably they may play at least an important a part in determining the relationship between executive management, non-executive 
directors and external audit, and the effectiveness of gatekeepers in corporate governance.

We earlier raised the potential for alternative frameworks to replace the existing governance paradigm, referring to the IIRF as an example. Why, however, would the commercial world want to reject the current paradigm, and who would be the key proponents? Perhaps regulators, investors and some other stakeholders might see merit in an alternative, but would corporate management support a tougher framework? Then, if the current paradigm were collectively rejected, what could replace it? While we see merit in the IIRF, it does not explicitly address the issues identified in our paper and suffers from a distinct lack of appreciation of social/psychological issues on decision-making. The IIRF would also appear to heavily rely on board directors in implementing the framework, without questioning whether continued trust in this governance agent remains warranted in view of past experience.

It is hoped that our analysis will prompt scholars and policy-makers to develop a deeper research agenda on the economic and behavioural factors affecting those charged with corporate governance. Existing standards, codes and regulations fall short by focussing on the economic incentives based on a 'carrot and stick' approach, with punishment threats and institutional prescriptions. In addition to economic incentives, scholars and policy-makers need to consider the impact of social/psychological and emotional factors on governance. Key factors to consider are those of auditor/client familiarity, empathy and 'blind-eye turning.' Theoretical and empirical research has already begun to examine the debate over 
auditor tenure/auditor turnover and fraud. We suggest that experimental research could examine what behavioural nudges to put in place to reduce the familiarity threat. A second area for future investigation is to attempt to understand groupthink and dominant personalities in corporate boards. A third area might investigate managerial fraud-entrapment and the slippery slope to fraud. This slippery slope argument suggests that behavioural remedies, rather than economic incentives and punishment threats, may be more effective at reducing fraud. Once these areas have been investigated, this might then enable institutions and regulators to develop codes, standards and regulations that address both the economic and behavioural factors affecting fraud-commission and egregious corporate activity. 


\section{References}

The Association of Certified Fraud Examiners, ACFE (2016). Report to the Nations on Occupational Fraud and Abuse. Available at: https://s3-uswest-2.amazonaws.com/acfepublic/2016-report-to-the-nations.pdf

Akerlof, G.A. and Romer, P.M. (1993). 'Looting: The Economic Underworld of Bankruptcy for Profit', Brookings Papers on Economic Activity, 24(2), pp. $1-74$.

Ahrens, T. and Khalifa, R. (2013). 'Researching the lived experience of corporate governance', Qualitative Research in Accounting \& Management, 10(1), pp. 4-30.

Auditing Practices Board (APB) (2009). 'APB ETHICAL STANDARD 3 (ES3 REVISED) LONG ASSOCIATION WITH THE AUDIT ENGAGEMENT. London: Financial Reporting Council.

Auditing Practices Board (APB) (2011). 'Auditor Scepticism: raising the bar', (Feedback paper). London: Financial Reporting Council.

Auditing Practices Board (APB) (2012). 'Professional Scepticism: Establishing a common understanding and reaffirming its central role in delivering audit quality', London: Financial Reporting Council.

Audit Inspection Unit (AIU) (2009). Annual Report. London: FRC.

Audit Inspection Unit (AIU) (2010). Annual Report. London: FRC.

Audit Inspection Unit (AIU) (2011). Annual Report. London: FRC.

Audit Inspection Unit (AIU) (2012). Annual Report. London: FRC.

Audit Quality Review (AQR) (2013). Annual Report. London: FRC.

Audit Quality Review (AQR) (2014). Annual Report. London: FRC.

Audit Quality Review (AQR) (2017). Audit firm specific reports 2017. Various. London: FRC.

Bazerman, M.H., G. Loewenstein and D.A. Moore (2002a). 'Auditor Independence, Conflict of Interest and the Unconscious Intrusion of Bias', Harvard NOM Research Paper No. 02-40. Available HTTP: http://ssrn.com/abstract_id=324261. Accessed: 1January, 2018. 
Bazerman, M.H., G. Loewenstein and D.A. Moore (2002b). 'Why Good Accountants Do Bad Audits', Harvard Business Review, 80(11), pp. 97 102.

Bazerman, M.H. and Malhotra, D. (2006). 'Economics wins, psychology loses, and society pays', in D. De Cremer, M. Zeelenberg, and K. Murnighan (eds), Social psychology and economics, pp. 263-280. Mahwah, NJ: Lawrence Erlbaum Associates.

Becker, G. S. (1974). 'A Theory of Social Interactions', Journal of Political Economy, 82 (6), pp. 1063-1093

Bédard, J. and Gendron, Y. (2010). 'Strengthening the Financial Reporting System: Can Audit Committees Deliver?', International Journal of Auditing, 14(2), pp. 174-210.

Bédard, J. and Wright, A. (1994). 'The Functionality of Decision Heuristics: Reliance on Prior Audit Adjustments in Evidential Planning', Behavioral Research in Accounting, 6 (Supplement), pp. 62-89.

Blue Ribbon Committee (1999). Report And Recommendations of the Blue Ribbon Committee on Improving the Effectiveness of Corporate Audit Committees, The New York Stock Exchange and the National Association of Securities Dealers, New York.

Bonner, S. E. and Pennington, N. (1991). 'Cognitive Processes and Knowledge as Determinants of Auditor Expertise', Journal of Accounting Literature, 10, pp. $1-50$.

Breeden, R. (2004). 'Report of Investigation by the Special Committee of the Board of Directors of Hollinger International Inc.' (Other members of the special committee: Paris G., Savage, W., Seitz, R.,), available at http://sec.gov/Archives/edgar/data/868512/000095012304010413/y01437e xv99w2.htm

Brennan, N. and Kirwan, C.E. (2015). 'Audit committees: practices, practitioners and praxis of governance', Accounting Auditing and Accountability Journal, 28(4), pp. 466-493.

Carcello, J.V., Vanstraelen, A. and Willenborg, M. (2009). 'Rules Rather than Discretion in Audit Standards: Going-Concern Opinions in Belgium', Accounting Review, 84(5), pp. 1395-1428.

Center for Audit Quality (CAQ) (2010). 'Deterring and Detecting Financial Reporting Fraud: A Platform for Action.’ Washington, DC: CAQ.

Clarke, F.L., Dean, G.W. and Oliver, K.G. (2003). Corporate Collapse: Regulatory, Accounting and Ethical Failure ( $2^{\text {nd }}$ ed.). Cambridge: Cambridge University Press. 
Coffee, J.C. (2001). 'The Acquiescent Gatekeeper: Reputational Intermediaries, Auditor Independence and the Governance of Accounting', Columbia Law School Center for Law and Economics Studies Working Paper, No.191, available at http://ssrn.com/abstract $=270944$

Coffee, J.C. (2003). 'Gatekeeper Failure and Reform: The Challenge of Fashioning Relevant Reforms.' Columbia Law School Center for Law and Economic Studies Working Paper no. 237. Available at: http://ssrn.com/abstract=447940.

Coffee, J.C. (2005). 'A Theory of Corporate Scandals: Why the U.S. and Europe Differ', Oxford Review of Economic Policy, 21(2), pp. 198-211.

Coffee, J.C. (2006). Gatekeepers: The Professions and Corporate Governance. Oxford: Oxford University Press.

Collier, P. (1997). 'Corporate Governance and Audit Committees', in Sherer, M. and Turley, S. (eds), Current Issues in Auditing ( $3^{\text {rd }}$ ed.), pp. 70-84. London: Sage Publications Ltd.

COSO (1992). 'Committee of Sponsoring Organizations of the Treadway Commission, Internal Control-Integrated Framework', AICPA.

Cullen, M.M. and Brennan, N.M. (2017).'Differentiating control, monitoring and oversight: influence of power relations on boards of directors - insights from investment fund boards', Accounting, Auditing \& Accountability Journal, 30(8), pp. 1867-1894.

Fanto, J. (2004). 'Whistleblowing And The Public Director: Countering Corporate Inner Circles', Oregon Law Review, 83, pp. 435-540.

Financial Reporting Council (FRC) (2003). 'The Combined Code on Corporate Governance', London: FRC.

Financial Reporting Council (FRC) (2011). 'Guidance on Board Effectiveness.' London: FRC.

Financial Reporting Council (FRC) (2013). 'Lab Project Report: Reporting of Audit Committees', London: FRC.

Financial Reporting Council (FRC) (2016). 'UK Corporate Governance Code.' Available at: https://www.frc.org.uk/Our-Work/Publications/CorporateGovernance/UK-Corporate-Governance-Code-April-2016.pdf

Fischhoff, B. (2002). 'Heuristics and Biases in Application', in T. Gilovich, D. Griffin and D. Kahneman (eds), Heuristics and Biases, pp. 730-748. Cambridge: Cambridge University Press.

Forbes, W. and Watson, R. (2010). 'Destructive Corporate Leadership and Board Loyalty Bias: A case study of Michael Eisner's long tenure at Disney 
Corporation', Working paper, presented at the Behavioural Finance Working Group Conference, Cass Business School, July 2010.

Francis, J.R. (2004). 'What Do We Know About Audit Quality', British Accounting Review, 36(4), pp. 345-368.

Gendron, Y. (2009). 'Discussion of 'The audit committee oversight process', Contemporary Accounting Research, 26(1), pp. 123-134.

Gendron, Y. and Bédard, J.C. (2006). 'On the constitution of audit committee effectiveness', Accounting, Organizations and Society, 31(3), pp. 211-239.

Gendron, Y. and Spira, L. (2009). 'What Went Wrong? The Downfall of Arthur Andersen and the Construction of Controllability Boundaries Surrounding Financial Auditing', Contemporary Accounting Research, 26(4), pp. 987 1027.

Gilovich, T., D. Griffin and D. Kahneman. (2002). 'Heuristics and Biases'. Cambridge: Cambridge University Press.

Glover S.M. and Prawitt, D.F. (2014). 'Enhancing Auditor Professional Skepticism: The Professional Skepticism Continuum', Current Issues in Auditing, 8(2), pp. 1-10.

Greenbury, R. (1995). Study Group on Directors' Remuneration: Final Report (The Greenbury Report). Confederation of British Industry (CBI). London.

Hampel, R. (1998). Committee on Corporate Governance, Final Report (The Hampel Report). London: Gee \& Co. Ltd.

Haynes, C. and Kachelmeier, S. (1998). 'The Effects of Accounting Contexts on Accounting Decisions: A Synthesis of Cognitive and Economic Perspectives in Accounting Experimentation', Journal of Accounting Literature, 17, pp. 97-136.

Higgs, D. (2003). 'Review of the Role and Effectiveness of Non-Executive Directors'. London: Department of Trade and Industry (DTI).

Hirst, D.E. and Koonce, L. (1996). 'Audit Analytical Procedures: A Field Investigation,', Contemporary Accounting Research, 13(2), pp. 457-486.

Hoggarth, R.M. (1991). 'A Perspective on Cognitive Research in Accounting', The Accounting Review, 66(2), pp. 277-290.

House of Lords Economic Affairs Committee (HoL). 2011. 'Auditors: Market Concentration and their Role. Volume I: Report', HL Paper 119-I (London: The Stationery Office). Available at: http://www.publications.parliament.uk/pa/ld201011/ldselect/ldeconaf/119/ 119.pdf. Accessed: 1 January, 2018. 
International Accounting Education Standards Board (IAESB). 2008.

'International Education Standard (IES) 8: Competence Requirements for Audit Professionals'. New York: International Federation of Accountants.

International Integrated Reporting Council (2013). The International Integrated Reporting Framework, available at: http://integratedreporting.org/wpcontent/uploads/2013/12/13-12-08-THE-INTERNATIONAL-IRFRAMEWORK-2-1.pdf

Joyce, E. and Biddle, G. (1981a). 'Anchoring and Adjustment in Probabilistic Inference in Auditing', Journal of Accounting Research, 19(1), pp. 120 145 .

Joyce, E. and Biddle, G. (1981b). 'Are Auditors' Judgments Sufficiently Regressive?', Journal of Accounting Research, 19(2), pp. 323-349.

Kellogg, I. and Kellogg, L.B. (1991). 'Fraud, Window Dressing and Negligence in Financial Statements', Commercial Law Series, New York: McGrawHill.

Krishnan, J., Rama, D. and Zhang, Y. (2008). 'Costs to Comply with SOX Section 404', Auditing: A Journal of Practice \& Theory, 27(1), pp. 169186.

Langevoort, D.C. (1998). 'Organized Illusions: A Behavioral Theory of Why Corporations Mislead Stock Market Investors (and Cause Other Social Harms)', University of Pennsylvania Law Review, 146(2), pp. 101-172.

Langevoort, D.C. (2001a). 'Monitoring: The Behavior Economics of Inducing Agents' Compliance with Legal Rules', University of Southern California Law School, Center for Law, Economics \& Organization. Research Paper, No. C01-7, available at http://papers.ssrn.com/abstract_id=276121

Langevoort, D.C. (2001b). 'The Human Nature of Boards: Law, Norms and the Unintended Consequences of Independence and Accountability', The Georgetown Law Journal, 89, pp. 797-832.

Larcker, D.F., Richardson, S.A. and Tuna, I. (2007). 'Corporate Governance, Accounting Outcomes, and Organizational Performance', The Accounting Review, 82(4), pp. 963-1008.

Leslie, M. (2010). 'The Wisdom of Crowds? Groupthink and Nonprofit Governance.' Florida Law Review, 62(5), pp. 1179-1226.

Long, G. (2009). 'Long Association with an Audit Client.' Certified Public Accountants. See: http://www.cpaireland.ie/docs/defaultsource/Students/Study-Support/P1-Auditing/long-association-with-anaudit-client.pdf?sfvrsn=0 
McNulty, T., Zattoni, A. and Douglas, T. (2013). 'Developing corporate governance research through qualitative methods: a review of previous studies', Corporate Governance: An International Review, 21(2), pp. 183198.

Messier, W.F., D.F. Prawitt and S.M. Glover (2012). Auditing and Assurance Services: A Systematic Approach. $8^{\text {th }}$ edition. New York, NY: The McGraw-Hill Companies, Inc.

Moore, D.A., L. Tanlu and Bazerman, M.H. (2010). 'Conflict of Interest and the Intrusion of Bias', Judgment and Decision Making, 5(1), pp. 37-53.

Morrison, M.A. (2004). 'Rush to judgment: the lynching of Arthur Andersen \& Co.', Critical Perspectives on Accounting, 15(3), pp. 335-375.

Padilla, A., Hogan, R. and Kaiser, R. (2007). 'The Toxic Triangle: Destructive Leaders, susceptible Followers and Conducive Environments', The Leadership Quarterly, 18(3), pp. 176-194.

Peecher, M.E. (1996). 'The Influence of Auditors' Justification Processes on Their Decisions: A Cognitive Model and Experimental Evidence', Journal of Accounting Research, 34(1), pp. 125-140.

Power, M. (1997). The Audit Society: Rituals of Verification. Oxford: Oxford University Press.

Prentice, R.A. (2000a). 'The SEC and MDP: Implications of the Self-Serving Bias for Independent Auditing', Ohio State Law Journal, 61(5), pp. 15971670 .

Prentice, R.A. (2000b). 'The Case of the Irrational Auditor: A Behavioral Insight into Securities Fraud Litigation', Northwestern University Law Review, 95(1), pp. 133-219.

Prentice, R.A. (2012). Submitted Written Testimony for the PCAOB Public Hearing Houston, TX Oct. 18, 2012. Available at: http://pcaobus.org/Rules/Rulemaking/Docket037/ps_Prentice.pdf. Accessed: 1 March, 2014.

Protiviti (2017). 'Sarbanes-Oxley Compliance Survey', Menlo Park, California, United States.

Public Company Accounting Oversight Board (PCAOB) (2008). 'Report on the PCAOB's 2004, 2005, 2006, and 2007 Inspections of Domestic Annually Inspected Firms', available at: http://pcaobus.org/Inspections/Documents/2008_12-05_Release_2008008.pdf (Accessed on 1 January, 2018).

Public Company Accounting Oversight Board (PCAOB) (2011a). 'Concept release on auditor independence and auditor firm rotation', release no. 
2011-006, available at:

http://pcaobus.org/rules/rulemaking/docket037/release_2011-006.pdf

(Accessed on 1 January, 2018).

Public Company Accounting Oversight Board (PCAOB) (2011b). 'Report on 2010 Inspection of Ernst \& Young LLP', release no. 104-2011-319:

Available at:

http://pcaobus.org/Inspections/Reports/Documents/2011_Ernst_Young_L

LP_US.pdf (Accessed on 1 January, 2018).

Public Company Accounting Oversight Board (PCAOB) (2012). 'Report on 2010 Inspection of Grant Thornton LLP', release no. 104-2012-109. Available at: http://pcaobus.org/Inspections/Reports/Documents/2012_Grant_Thornton _LLP.pdf (Accessed on 1 January, 2018).

Public Company Accounting Oversight Board (PCAOB) (2014). Statement by Martin Baumann, chief auditor of the Public Company Accounting Oversight Board, quoted by the Wall Street Journal, 24 January, 2014.

Public Company Accounting Oversight Board (PCAOB) (2015). 'Concept release on audit quality indicators. Release No. 2015-005', available at: http://pcaobus.org/Rules/Rulemaking/Docket\%20041/Release_2015_005. pdf (Accessed on 1 January, 2018).

Rabin, M. (2002). 'A Perspective on Psychology and Economics', Economics Department, University of California (Berkeley) Working Paper E02-313, available at http://repositories.cdlib.org/iber/econ/E02-313

Rockness, H. and Rockness, J. (2005). 'Legislated Ethics: From Enron to Sarbanes-Oxley, the Impact on Corporate America', Journal of Business Ethics, 57(1), pp. 31-54.

Scharff, M.M. (2005). 'Understanding WorldCom's Accounting Fraud: Did Groupthink Play a Role?', Journal of Leadership \& Organizational Studies, 11(3), pp. 109-118.

Schrand, C.M. and Zechman, S.L.C. (2012). ,Executive Overconfidence and the Slippery Slope to Financial Misreporting', Journal of Accounting and Economics, 53(1), 311-329.

Smith, R. (2003). 'Audit Committees: Combined Code Guidance', Financial Reporting Council (FRC). London.

Smith, J.F. and Kida, T. (1991). 'Heuristics and Biases: Expertise and Task Realism in Auditing', Psychological Bulletin, 109(3), pp472-489.

Sunstein, C.R., Jolls, C. and Thaler, R.H. (1998). 'A Behavioral Approach to Law and Economics,' Stanford Law Review, 50, pp. 1471-1550. 
Thornburgh, D. (2002). 'First Interim Report of Dick Thornburgh, Bankruptcy Court Examiner', available at

http://www.klgates.com/files/upload/WorldCom_Examiner_Report_firstin terim.pdf

Thornburgh, D. (2003). 'Second Interim Report of the Court Appointed Bankruptcy Examiner', available at http://www.klgates.com/files/upload/Worldcom_Report2.pdf

Thornburgh, D. (2004). 'Third and Final Report of Dick Thornburgh, Bankruptcy Court Examiner', available at http://www.klgates.com/files/upload/WorldCom_Report_final.pdf

Turnbull, N. (1999). Internal Control: Guidance for Directors on the Combined Code (The Turnbull Report). London: ICAEW.

Turner, L.E. (2005). 'Reply to Mary Morrison', Critical Perspectives on Accounting, 16(1), pp. 63-64.

U.S. General Accounting Office (1996). Pub. GAO/AIMD-96-123, Resolution Trust Corporation's 1995 and 1994 Financial Statements.

U.S. Senate Permanent Subcommittee on Investigations (2011). Wall Street and the Financial Crisis: Anatomy of a Financial Collapse. April 13, 2011. Joint Report of the Majority and Minority Staffs. GPO labeled as S. Hrg. 112-675 - Volume 5 - Part I, II, III \& IV.

U.S. Senate Permanent Subcommittee on Investigations (2013). JP Morgan Chase Whale Trades: A Case History of Derivatives Risks and Abuses: Hearing before the Permanent Subcommittee on Investigations of the Committee on Homeland Security and Governmental Affairs, United States Senate, One Hundred Thirteenth Congress, First Session, March 15, 2013, Vol. 1 Vol. 2.

Waller, W. and Felix, W.L. (1984). 'The Auditor and Learning from Experience: Some Conjectures', Accounting, Organization and Society, 9(3/4), pp. 383-406.

Weick, K.E. (1983). 'Stress in Accounting Systems', The Accounting Review, 58(2), pp. 350-369.

Whittington, R. (2011). 'The practice turn in organization research: towards a disciplined transdisciplinarity', Accounting, Organizations and Society, 36(3), pp. 183-186.

Wolnizer, P. (1987). 'Auditing as Independent Authentication'. Sydney: University Press. 


\title{
Appendix: Hollinger group structure
}

\author{
Black and Radler's Effective Economic Ownership in Hollinger \\ As of December 31, 2002
}

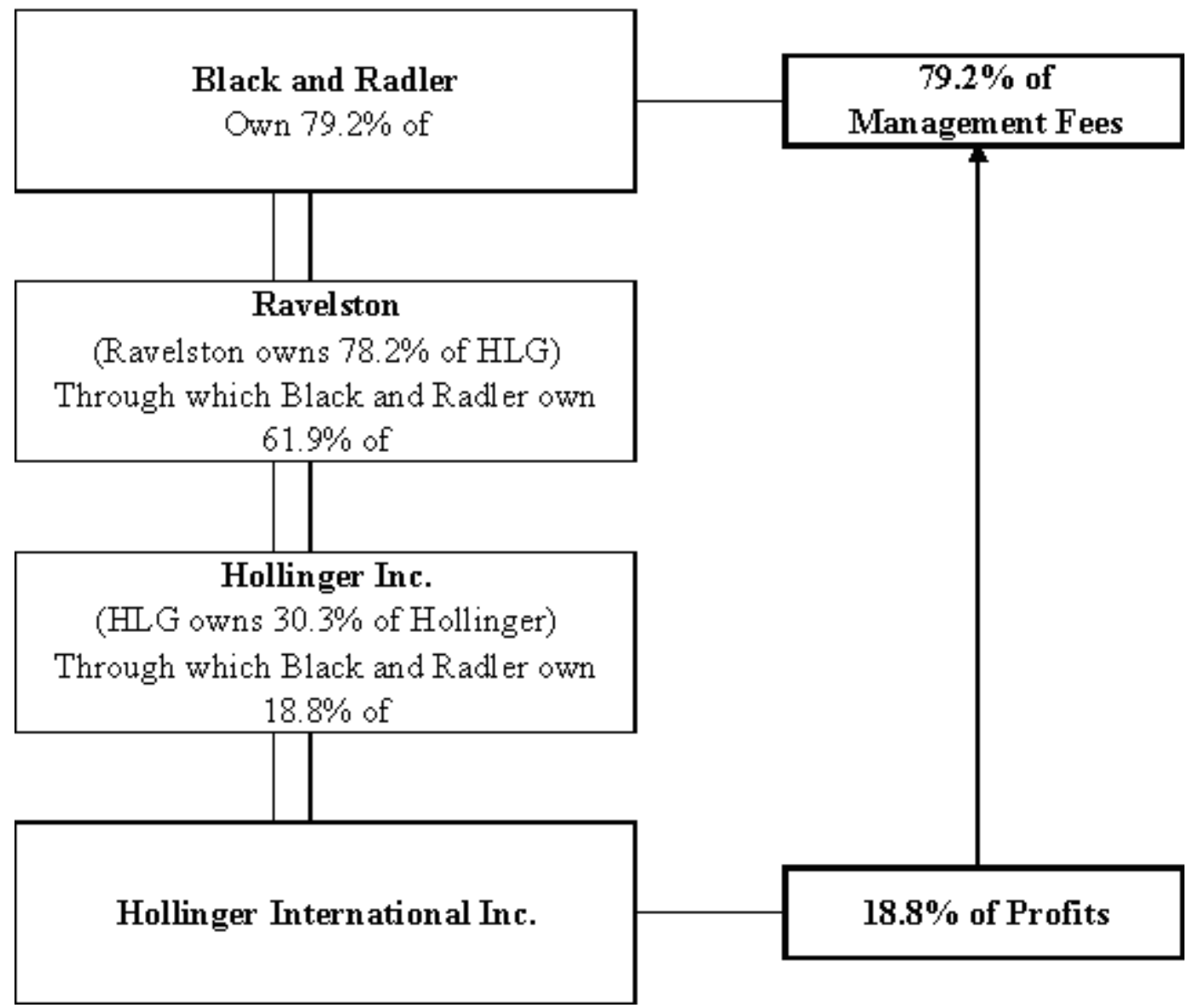

\footnotetext{
${ }^{\mathrm{i}}$ The authors wish to thank an anonymous reviewer for the suggestion to consider the potential of alternative paradigms to address the issues identified in this paper.

ii AAERs summarise financial reporting related enforcement actions re civil lawsuits brought by the SEC in federal court, and notices and orders and/or settlement of administrative proceedings.

iii Thornburgh (2003, p. 185).

iv Thornburgh (2003, p.178).

${ }^{\vee}$ SEC, http://www.sec.gov/litigation/complaints/complr17722.htm.

${ }^{\text {vi }}$ http://www.sec.gov/litigation/admin/34-48328.htm

${ }^{\text {vii }}$ http://www.sec.gov/litigation/complaints/comp17954.htm

viii Margin normalization refers to adjustments to a financial metric to provide a better estimate for its expected future value. However, careful evaluation of the assumptions underlying normalization adjustments is advised to ensure their legitimacy.

${ }^{\text {ix }}$ Hollinger International Form 14A (2001, p. 13).

${ }^{\mathrm{x}}$ Breeden (2004, p. 495).

${ }^{\mathrm{xi}}$ Breeden (2004, p. 500).

xii Breeden (2004, p. 503).

${ }^{x i i i}$ While the activity and practice of external audit has come under searching examination over the last twenty years, there has been less focus on the effectiveness of audit committees (but note work by Gendron and Bédard, 2006; Gendron, 2009; Bédard and Gendron, 2010; the FRC, 2013; Brennan and Kirwan, 2015).

${ }^{\text {xiv }}$ SEC complaint against KPMG, http://www.sec.gov/litigation/complaints/comp17954.htm

${ }^{\mathrm{xv}}$ For e.g., Prentice (2000a,b; 2012); Langevoort (1998, 2001a,b); Fischhoff (2002); Fanto (2004).
} 
${ }^{x v i}$ The PCAOB (2014) suggested that more than one in three inspected audits were so deficient that the auditors should not have signed off, while the AIU regularly points out significant (and rather persistent) flaws in inspected audits. Still, this may not be indicative of a trend in the rate of audit qualifications, or type I/II errors (Coffee, 2006; Carcello et al., 2009).

${ }^{x v i i}$ The Association of Certified Fraud Examiners (2016) suggests that organizations worldwide lose some 5 percent of revenue to fraud. We suggest that the combined impact of fraud and various inefficiencies \& losses due to poor governance is significantly larger. The economic cost of egregious misconduct is enormous. Baring's bank went under as a result of a loss of some $£ 1$ billion. The US Savings \& Loan crisis cost approximately $\$ 500$ billion (GAO, 1996). The GFC is counted in terms of percentages of GDP lost for affected economies.

${ }^{x v i i i}$ Based on data by Krishnan et. al. (2008) and Protiviti (2017), audit fees more than doubled in the first year of SOX compliance with persistently extra costs associated with subsequent s404 compliance testing. 